\section{Ultrasound-assisted dewatering of crude oil from Kumkol oilfield}

Zh.K. Nadirova ${ }^{1}$, O.P. Ivakhnenko ${ }^{2}$, M.K. Zhantasov ${ }^{1}$, G.Zh. Bimbetova ${ }^{1}$ K.S. Nadirov ${ }^{*}$

${ }^{1}$ M. Auezov South Kazakhstan University, Shymkent, Kazakhstan ${ }^{2}$ Heriot-Watt University, Edinburgh, Great Britain "E-mail: nadirovkazim@mail.ru
Reducing the water content of crude oil is a necessary step in preparing oil for transportation and processing. This task is complicated by the presence of stable water-in-oil emulsions. The most widely used approach to oil demulsification is exploring chemical demulsifiers. However, the high cost and impossibility of regenerating the latter require the search for new ways to destroy water-oil emulsions. One of the promising areas is the use of ultrasound. This paper presents the results of studies on the ultrasonic treatment of four samples of emulsions with different water content $(8.74 ; 15 ; 25$ and 30 vol.\%) based on oil from the Kumkol oilfield (Kazakhstan). Samples of emulsions were subjected to ultrasonic action at a frequency of $40 \mathrm{kHz}$ for 5-60 min at a temperature of $70 \pm 1^{\circ} \mathrm{C}$, followed by settling for $40 \mathrm{~min}$ at the indicated temperature. The influence of the initial water content in the emulsion, the acoustic intensity, as well as the duration of ultrasonic treatment on the dewatering ratio was investigated. It was found that the residua water content in the oil was 5.04- 7.82 vol.\%. Ultrasonic treatment of crude oil from the Kumkol oilfield can be used for preliminary dewatering, to subsequently reduce the consumption of chemical demulsifiers.

Keywords: crude oil; water-oil emulsion; demulsification; ultrasonic treatment; demulsification ratio.

\section{Құмкөл кен орнының шикі мұнайын ультрадыбыс көмегімен сусыздандыру}

Ж.К. Надирова ${ }^{1}$, О.П. Ивахненко ${ }^{2}$ М.К. Жантасов ${ }^{1}$, Г.Ж. Бимбетова ${ }^{1}$ К.С. Надиров ${ }^{1 *}$

${ }^{1}$ М. Әуезов атындағы Оңтүстік Қазақстан университеті, Шымкент, Қазақстан ${ }^{2}$ Херриот-Ватт университеті, Эдинбург, Ұлыбритания *E-mail: nadirovkazim@mail.ru

Шикі мұнайдағы су құрамының төмендеуі мұнайды тасымалдауға және қайта өңдеуге дайындау кезіндегі қажетті операция болып табылады. Бұл мәселе «мұнайдағы су»сияқты тұрақты эмүльсиялардың болуымен қиындатылған. Мұнайдың деэмульсациясь үшін ең көп қолданылатын әдіс - химиялық деэмульгаторларды қолдану. Алайда, олардың құнының жоғары болуы және қайта қалпына келмегендіктен мұнай-сулы эмульгаторларды ыдыратудың жаңа жолдарын іздестіруді талап етеді. Ультрадыбысть қолдану перспективалық бағыттардың бірі болып табылады. Осы жұмыста Құмкөл (Қазақстан) кен орнының мұнайы негізінде құрамындағы су мөлшері әртүрлі болатын (8,74; 15; 25 және 30 көлемдік \%) эмульсиялардың төрт үлгісін ультрадыбыстық өңдеудің зерттеу нәтижелері ұсынылған. Эмульсиялардың үлгілері $70 \pm 1^{\circ} \mathrm{C}$ температурада 5-60 минут ішінде 40 кГц жиілікте ультрадыбыстық әсерге ұшырап, кейіннен ось температурада 40 минут тұндырылды. Эмульсиядағы судың бастапқы құрамының, ультрадыбыстық қарқындылығының, сондай-ақ эмульсияның дегидратация дәрежесіне ультрадыбыстық өңдеу ұзақтығының әсері зерттелді. Мұнайдағы судың қалдық мөлшері 5,04-7,82 көлем \%. анықталынды. Құмкөл кен орнының шикі мұнайын ультрадыбыстық өңдеу химиялық деэмүльгаторлардың шығынын азайту мақсатында алдын ала дегидратация үшін пайдаланылуы мүмкін.

Түйін сөздер: шикі мұнай; су-мұнай эмульсиясы; деэмульсация; ультрадыбыстық өңдеу; деэмульсация дәрежесі.

\section{Обезвоживание сырой нефти месторождения Кумколь с использованием ультразвука}

Ж.К. Надирова ${ }^{1}$, О.П. Ивахненко ${ }^{2}$ М.К. Жантасов ${ }^{1}$, Г.Ж.Бимбетова ${ }^{1}$ К.C. Надиров ${ }^{1^{*}}$

${ }^{1} Ю$ жно-Казахстанский университет им. М. Ауэзова, Шымкент, Казахстан 'Университет Херриот-Ватт, Эдинбург, Великобритания *E-mail: nadirovkazim@mail.ru
Снижение содержания воды в сырой нефти является необходимой операцией при подготовке нефти к транспортировке и переработке. Эта задача осложнена наличием устойчивых эмульсий типа "вода в нефти». Наиболее широко используемым подходом к деэмульсации нефти является использование химических деэмульгаторов. Однако дороговизна и невозможность регенерации последних требует поиска новых путей разрушения водонефтяных эмульсий. Одним из перспективных направлений представляется использование ультразвука. В настоящей работе представлены результать исследований по ультразвуковой обработке четырех образцов эмульсий с разным содержанием воды (8,74; 15; 25 и 30 об.\%) на основе нефти месторождения Кумколь (Казахстан). Образцы эмульсий подвергались ультразвуковому воздействию частотой 40 кГц в течение 5-60 мин при температуре $70 \pm 1^{\circ} \mathrm{C}$ с последующем отстаиванием в течение 40 мин при указанной температуре. Исследовалось влияние исходного содержания водь в эмульсии, интенсивности ультразвука, а также продолжительности ультразвуковой обработки на степень обезвоживания эмульсии. Найдено, что остаточное содержание водь в нефти составило 5,04-7,82 об.\%. Ультразвуковая обработка сырой нефти месторождения Кумколь может быть использована для предварительного обезвоживания, с целью последующего снижения расхода химических деэмульгаторов.

Ключевые слова: сырая нефть; водонефтяная эмульсия; деэмульсация; ультразвуковая обработка; степень деэмульсации. 


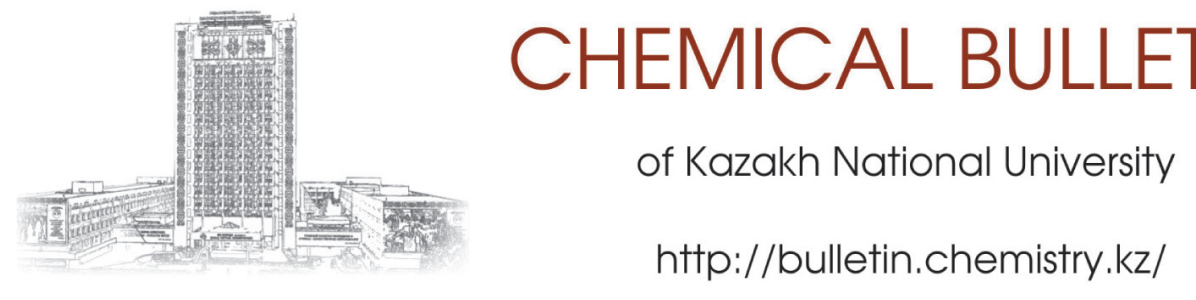

UDC 665.662

https://doi.org/10.15328/cb1217

\title{
Ultrasound-assisted dewatering of crude oil from Kumkol oilfield
}

\author{
Zh.K. Nadirova ${ }^{1}$, O.P. Ivakhnenko ${ }^{2}$, M.K. Zhantasov ${ }^{1}$, \\ G.Zh. Bimbetova ${ }^{1}$, K.S. Nadirov ${ }^{1^{*}}$ (D)
}

${ }^{1}$ M. Auezov South Kazakhstan University, 5 Tauke Khan Ave., Shymkent 160012, Kazakhstan ${ }^{2}$ Heriot-Watt University, Campus The Avenue, Edinburgh EH14 4AS, Great Britain

*E-mail: nadirovkazim@mail.ru

\section{Introduction}

The oil obtained from wells (crude oil) always contains water, as well as salts dissolved in it. These impurities cause serious difficulties in the processing and transportation of crude oil and also lead to equipment corrosion. In this sense, before being transported and used in refining operations, the content of water (and, consequently, salts) should be significantly reduced until acceptable values are reached (usually, no more than 1 vol.\% of water). This task is very difficult due to the presence of so-called stable water-in-oil (W/O) emulsions [1-4]. For the successful separation of water from oil, it is necessary to destroy the emulsions; while water droplets coalesce, form larger globules, and are settled by gravity (preferably at elevated temperatures).

The most common method for crude oil pretreatment is chemical demulsification [5-10]; the use of commercial chemical demulsifiers achieves dewatering rates above 90\% $[5,6]$. However, chemical reagents are costly and not recyclable after adding to the oil. Besides, a part of chemical demulsifiers, contained in separated water, is added to the wastewater, thereby polluting it. Therefore, alternative ways of crude oil dewatering are extremely important. One of the possible options of crude oil pre-treatment is the use of ultrasound (US) [11-15]. This approach is considered a good method for crude oil dewatering/demulsification from the position of environmental protection.

The displacement effect underlies the mechanism of crude oil demulsification using US irradiation [16]. Under the conditions of US treatment, the water and oil drops move, gather and collide, forming bigger globules; under the influence of gravity, water droplets are settled, thereby separating from the oil.
Despite the promise of this line of research, the reports about systematic investigations of US demulsification are limited up to now. In this work, we investigated the applicability of US treatment of crude oil of Kumkol oilfield (Kazakhstan). To the best of our knowledge, there are no papers in reputable journals dealing with US pre-treatment of crude oil of Kumkol oilfield in order to reduce water content in the W/O emulsion.

\section{Experiment}

2.1 Preparation and characterization of W/O emulsion

Water-in-oil (W/O) emulsions were prepared using a crude oil supplied from Kumkol oilfield (Kazakhstan) with the following characteristics (provided by the supplier): density $\left(20^{\circ} \mathrm{C}\right)$ $819 \mathrm{~kg} / \mathrm{m}^{3}$; kinematic viscosity $\left(20^{\circ} \mathrm{C}\right) 9.4 \mathrm{~mm}^{2} / \mathrm{s}$; water content 8.74 vol.\%; salt content $102 \mathrm{~kg} / \mathrm{m}^{3}$; asphaltenes content 0.49 wt.\%. To prepare W/O emulsions with different water content, a pre-determined amount of $102 \mathrm{~g} / \mathrm{L} \mathrm{NaCl}$ aqueous solution was added to the initial sample; the mixture was stirred using a mechanical stirrer (Mslos18-23) at $2800 \mathrm{rpm}$ for $10 \mathrm{~min}$. The droplet size distribution (DSD) in as-prepared W/O emulsion was measured by the light scattering technique (Mastersizer 2000, Malvern). Light microimages were taken using an optical microscope Levenhuk D 70L.

\subsection{Experimental process}

For all ultrasound-assisted demulsification experiments, $100 \mathrm{ml}$ of as-prepared W/O emulsion sample was placed in a graduated glass bottle, and the bottle was introduced into the centre of the ultrasonic bath ( $« S p e c o s » V-40$, Russia). Ultrasound (US) exposure (frequency of $40 \mathrm{kHz}$ ) was applied to the content of a bottle for $5,10,20,30,40,50$ and $60 \mathrm{~min}$ at $70 \pm 1^{\circ} \mathrm{C}$. The acoustic intensity was varied from $0.25 \mathrm{~W} / \mathrm{cm}^{3}$ (that means US 
power $25 \mathrm{~W}$ taking into account the volume of emulsion in our case) to $1.25 \mathrm{~W} / \mathrm{cm}^{3}$. After the US treatment, a bottle was transferred to a water bath $\left(70 \pm 1^{\circ} \mathrm{C}\right)$ and was kept there for 40 min. To monitor the process of phases separation, the position of the water/emulsion interface was used.

The demulsification ratio (D) was calculated from the following equation:

$$
D(\%)=\frac{V_{s w}}{V_{o w}} \times 100 \%
$$

Where $\mathrm{V}_{\mathrm{sw}}$ and $\mathrm{V}_{\mathrm{ow}}$ are the volume of separated water and the emulsion's original volume of water, respectively.

In the case of determining the demulsification ratio without using US irradiation, W/O emulsion was placed water bath $\left(70^{\circ} \mathrm{C}\right)$ and was kept there for $40 \mathrm{~min}$, as in the case of US treated samples.

The relative demulsification efficiency $(\psi)$ was calculated by using the following equation:

$$
\psi=\frac{D_{u s}}{D_{g}}
$$

Where $D_{\text {us }}$ and $D_{g}$ are the demulsification ratios for US forced and without US treatment (i.e. caused by gravitational sedimentation of water droplets), respectively.

Residual water content in the emulsion was determined by using the Dean-Stark method.

For each case, the experiments were conducted three times to obtain the mean as well as the standard deviation of the $D$. In cases where the $D$ value deviated by more than two standard deviations from the mean, the corresponding experiment was repeated. All figures show the means for three obtained values.

\section{Results and Discussion}

It is known from the literature that the use of a frequency of US irradiation above $45 \mathrm{kHz}$ is impractical for crude oil demulsification [17]; therefore this parameter was kept constant. The influence of the following factors on the process of dewatering of oil emulsion was investigated: US treatment duration, initial water content, as well as acoustic intensity.

3.1 The effect of ultrasound exposure duration and initial water content on the demulsification ratio

Preliminary experiments have shown that the coalescence of water droplets in the emulsion begins already in the first minutes of US exposure. Therefore, the duration of US treatment was varied from 5 to $60 \mathrm{~min}$.

Figure 1 demonstrates the dependence of the demulsification ratio on the US treatment duration for an emulsion with different initial water content $(8.74 \%$ (initial emulsion, without adding $\mathrm{NaCl}$ aqueous solution); $15 \%$; $25 \%$; $30 \%$ ). The acoustic intensity was settled at $0.75 \mathrm{~W} / \mathrm{cm}^{3}$. The values of $D$ at time $=0$ means demulsification ratio without US treatment.

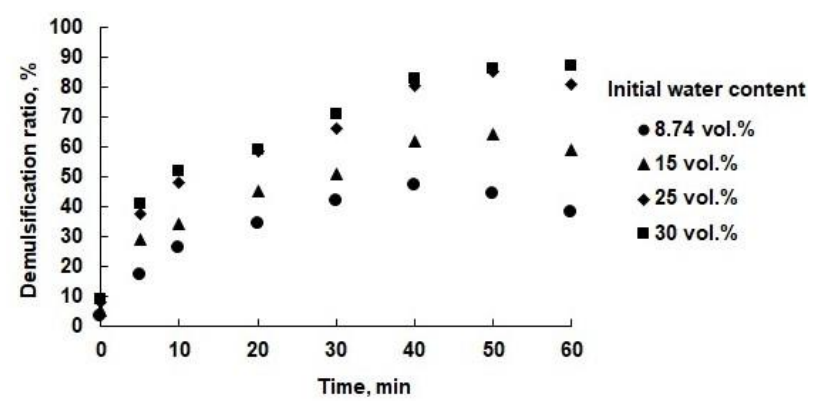

Figure 1 - The effect of US exposure duration and initial water content on demulsification ratio of the W/O emulsion (US frequency $40 \mathrm{kHz}$, acoustic intensity $0.75 \mathrm{~W} / \mathrm{cm}^{3}$ )

As can be observed in Figure 1, with an increase in the US treatment duration, the demulsification ratio (D) began also to increase, up to 40 minutes. Further changes in the $D$ values depended on the initial water content of the emulsion: for the initial emulsion (with the lowest water content), with the US treatment duration exceeding $40 \mathrm{~min}$, the $\mathrm{D}$ value dropped and reached $29 \%$ at $60 \mathrm{~min}$ (the maximum $\mathrm{D}$ value was $41 \%$ at 40 min). For emulsions with a higher initial water content $(15,25$ and 30 vol.\%), the $D$ values practically did not fall over time and reached a plateau. It took a long time (40 min or more) for water droplets to aggregate and form larger drops. But an excessively long time of US exposure raise the temperature of $\mathrm{W} / \mathrm{O}$ emulsion and the acoustic cavitation threshold is reduced. In this case, the formed large water droplets are dispersed again, which reduces the demulsification ratio. Increasing the initial water content increases the acoustic cavitation threshold and the effect of decreasing $D$ becomes weaker.

An increase in the demulsification ratio with an increase in the initial water content in our experiments is in good agreement with the literature data $[17,18]$. The more water droplets are in the same volume of the emulsion, the easier it is for these droplets to combine to form larger droplets. Further, under the influence of gravity, these droplets settle, ensuring the separation of the emulsion.

Several components of oil, in particular, asphaltenes, resin, macromolecular paraffins, and other natural emulsifiers are responsible for the formation of W/O emulsions. These components, being adsorbed at the water-oil interface, prevent the coalescence of water droplets. Thus, another reason for the increase in the demulsification rate is a decrease in the concentration of natural demulsifiers in artificially created emulsions upon dilution with water of the original W/O sample. 
Besides, it was expected that as-prepared model emulsions (in our case, emulsions with a water content of 15, 25 , and 30 vol.\%) undergo easier destruction due to less adsorption of natural demulsifiers at the W/O interface.

However, in [13] the opposite picture was observed: with an increase in the initial water content in the emulsion, the demulsification ratio value decreased with the same characteristics of the US treatment. The authors of this article gave the following explanation for the observed phenomenon: the increase of initial water content requires more US waves to the convergence of water droplets and it is expected that with constant US exposure parameters, an increase in the initial water content should reduce the demulsification ratio.

Figure 2 depicts the influence of initial water content and US treatment duration on relative demulsification efficiency $(\psi)$.

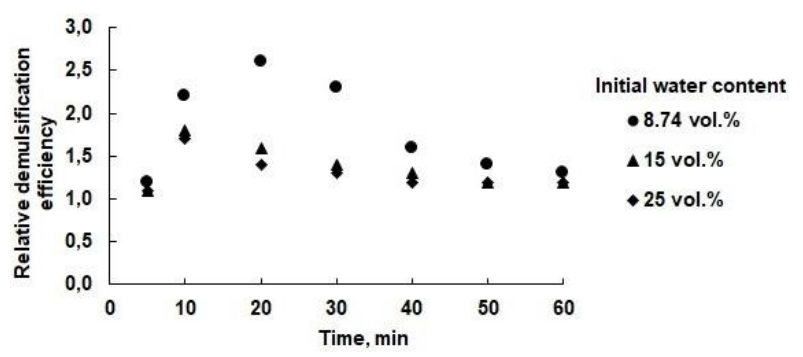

Figure $\mathbf{2}$ - Influence of initial water content and US treatment duration on relative demulsification efficiency

For all three of studied emulsion samples, with an increase in the duration of US irradiation from 5 to $10 \mathrm{~min}$, the value of $\psi$ increased, and this effect was manifested the stronger, the lower was the initial concentration of water in the emulsion (increase in $\psi$ by 82,64 and 55\% for $8.74,15$ and 25 vol.\% of water, accordingly). A further increase in the duration of US irradiation to $20 \mathrm{~min}$ increased the value of $\psi$ by a factor of 2.2 for an emulsion containing 8.74 vol.\% of water. For the other two emulsions with higher water content, the value of $\psi$ decreased; at US irradiation time of $60 \mathrm{~min}$, the relative demulsification efficiency for all three emulsion samples was approximately close (1.20-1.25). Since the $\psi$ value illustrates the contribution of the ultrasonic component in comparison with the contribution of gravitational settling (that is, in natural conditions), it can be concluded that the effect of ultrasonic exposure is stronger for an emulsion with relatively low water content. Indeed, the lower the content of water droplets, the lower the likelihood of their coalescence and subsequent precipitation. Upon reaching a certain threshold value of the emulsion processing time US (60 $\mathrm{min}$ in our case), the effect of the initial water content is levelled and the degree of influence of the ultrasonic component on demulsification efficiency becomes practically the same for samples with different water content.
3.2 The effect of acoustic intensity on the demulsification ratio

The dependence of the W/O demulsification ratio on the acoustic intensity applied to the sample is presented in Figure $3(a, b)$.

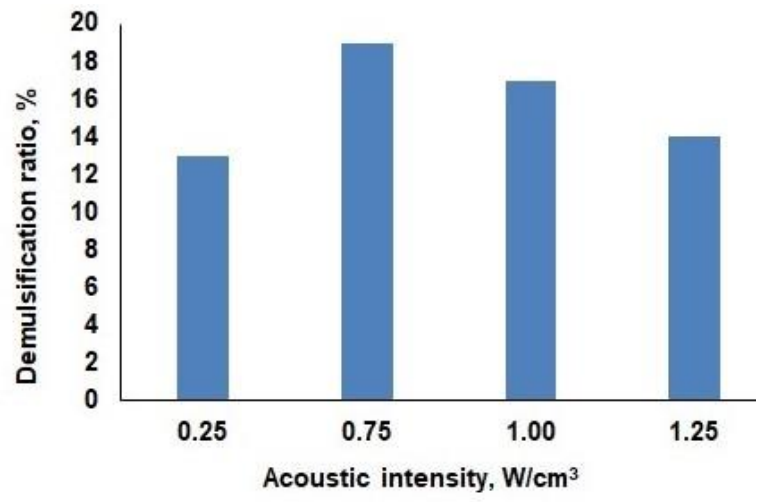

(a)

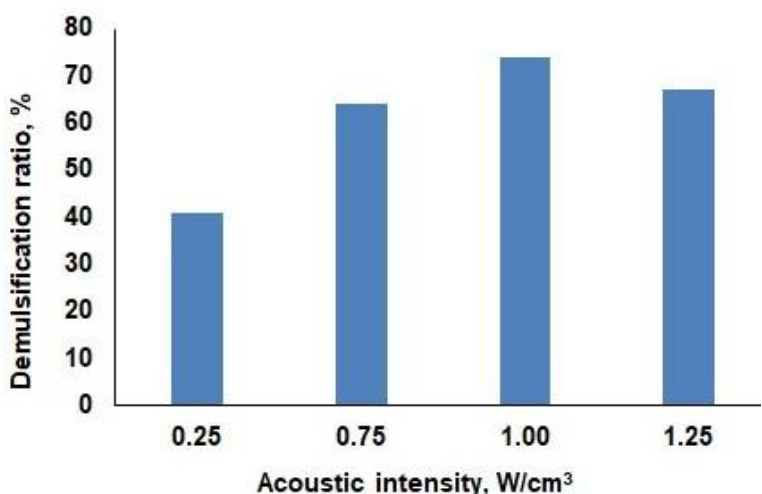

(b)

Figure 3 - The effect of acoustic intensity on demulsification rate of the W/O emulsion (US frequency $40 \mathrm{kHz}$, US exposure duration $40 \mathrm{~min}$, initial water content 8.74 (a) and 30 (b) vol.\%)

As shown in Figure 3, the enhance of acoustic intensity from 0.25 to $0.75 \mathrm{~W} / \mathrm{cm}^{3}$ increases the demulsification ratio at the constant value of US treatment duration $(40 \mathrm{~min}$ ) for both $W / O$ samples. A further change in the $D$ depended on the initial water content in the emulsion. For an emulsion containing 8.74 vol.\% water, an increase in acoustic intensity negatively affected the demulsification ratio (Figure 3, a). In the case of a 30 vol.\% water content, the $D$ value increases with acoustic intensity up to $1.00 \mathrm{~W} / \mathrm{cm}^{3}$ and then decreases (Figure $3, \mathrm{~b}$ ). This circumstance is apparently explained by the following. Under the influence of US radiation, water droplets move chaotically, while the probability of collision of water droplets with the formation of larger globules increases. However, US radiation can also lead to disaggregation of water droplets and their dispersion in oil; at the same time, the efficiency of the water-oil separation process becomes lower. 
3.3 The effect of water content in emulsion and US irradiation on median drop size of water

The median drop size distribution (DSD, D(0.5)) of water in initial W/O emulsions was found to be dependent on the water content of the emulsion (Table 1).

The data presented in Table 1 explain the more than threefold increase in the demulsification ratio for an emulsion with 30 vol.\% of water compared to that containing 8.74 vol.\% of water (Figure 3). As can be seen from the Table, with an increase in water content by 3.43 times (from 8.74 to 30 vol.\%), the average diameter of water droplets increases only 1.34 times. If we assume that the water droplets are spherical, the droplet volume increases 2.43 times. Thus, with an increase in the water content in the emulsion, the number of water droplets in the same volume of the emulsion increases; accordingly, the probability of droplet coalescence grows when exposed to ultrasound.

After applying US irradiation, the water droplet size increased for all tested emulsion samples (see Figure 4 in case of 8.74 vol.\% of water and US treatment duration of $40 \mathrm{~min}$ ).

Figure 4 demonstrates that US irradiation leads to the coarsening of water droplets in the emulsion, ensuring the subsequent $\mathrm{W} / \mathrm{O}$ separation under gravity.

Table 1 - Median drop size distribution (DSD, D(0.5)) of water in initial W/O emulsions

\begin{tabular}{lllll}
\hline Initial water content, vol.\% & 8.74 & 15 & 25 & 30 \\
\hline DSD, D(0.5), $\mu \mathrm{m}$ & 29 & 34 & 38 & 39
\end{tabular}

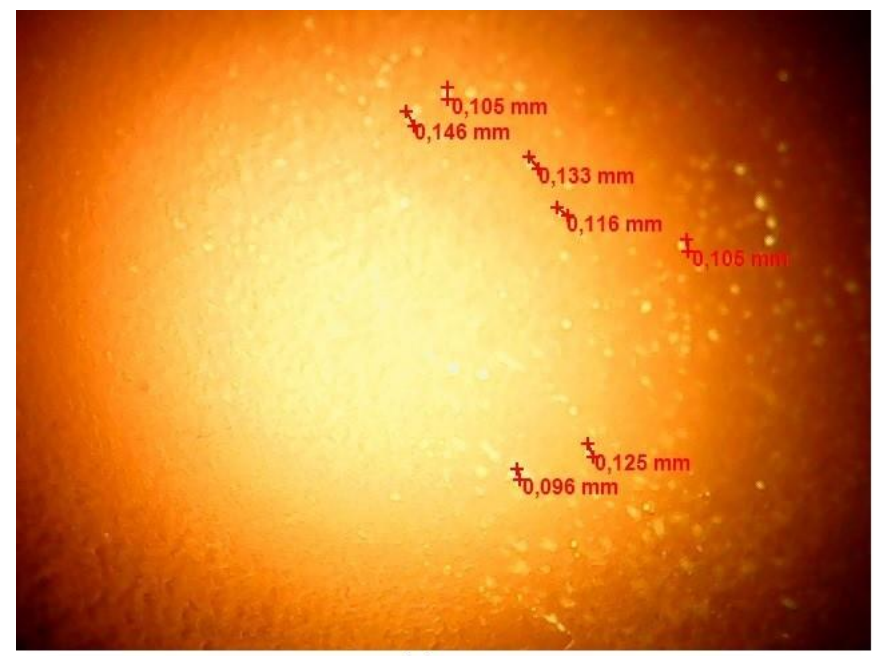

(a)

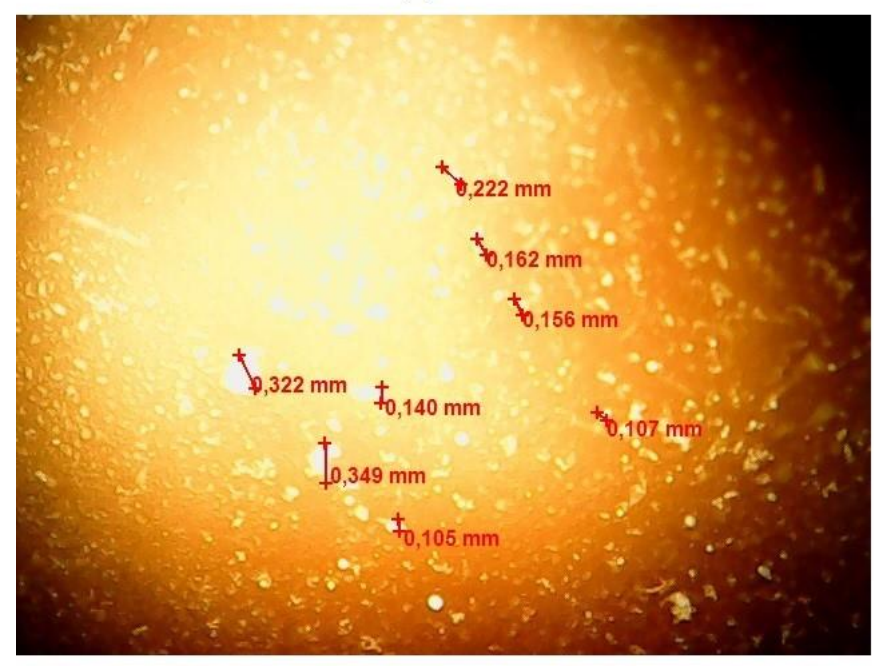

Figure 4 - Microscopic images of water droplets in an initial (a) and the US treated (US frequency $40 \mathrm{kHz}$, US exposure duration 40 min, initial water content 8.74 vol.\%, (b)) W/O emulsions 
Table 2 - Residual water content in the US treated W/O emulsions

\begin{tabular}{llll}
\hline Initial water content, vol.\% & US treatment duration, min & Acoustic intensity, W/cm & Residual water content, vol.\% \\
\hline 8.74 & 40 & 0.75 & 5.04 \\
15 & 50 & 0.75 & 6.53 \\
25 & 50 & 1.00 & 6.87 \\
30 & 50 & 1.00 & 7.82 \\
\hline
\end{tabular}

3.4 Discussion of the applicability of ultrasonic demulsification of oil from the Kumkol field without the use of chemical demulsifiers

The lowest values of the residual water content after US treatment and settling $\left(70 \pm 1^{\circ} \mathrm{C}, 40 \mathrm{~min}\right)$ in each of the four samples of W/O emulsions are presented in Table 2; the processing conditions (US treatment duration, acoustic intensity) under which these residual water contents were achieved are also given.

It can be seen that the residual water content in all emulsion samples remained quite high. Therefore, US treatment alone is not enough to demulsify the crude oil of the Kumkol oilfield. However, this treatment can be used as a preliminary stage of dewatering to subsequently reduce the consumption of chemical demulsifiers.

\section{Conclusions}

Demulsification of four W/O emulsions with different water content by using ultrasonic pre-treatment at the frequency of $40 \mathrm{kHz}$ has been investigated in the present work. The effect of ultrasound treatment duration, the initial water content in the emulsion, as well as acoustic intensity on the demulsification efficiency was analyzed. Maximum demulsification ratio was achieved by optimizing the treatment duration and acoustic intensity, ensuring the residual water content of 5.04-7.82 vol.\%, depending on the initial water content in the emulsion. Excessive application ultrasound irradiation reduces the efficiency of the process of separating water from oil due to the destruction of water globules. It has been demonstrated that ultrasound pretreatment of crude oil of Kumkol oilfield (Kazakhstan) can be applied as a preliminary stage of demulsification to further reduce the consumption of chemical reagents.

\section{Acknowledgements}

This research was funded by the Science Committee of the Ministry of Education and Science of the Republic of Kazakhstan (Grant No. AP08857586).

\section{References (GOST)}

1 Umar A. A., Saaid I. B. M., Sulaimon A. A., Pilus R. B. M. A review of petroleum emulsions and recent progress on water-incrude oil emulsions stabilized by natural surfactants and solids // Journal of Petroleum Science and Engineering. - 2018. - Vol.165. - P.673-690.

2 Czarnecki J., Tchoukov P., Dabros T. Possible role of asphaltenes in the stabilization of water-in-crude oil emulsions // Energy \& Fuels. - 2012. - Vol.26, Is.9. - P.5782-5786.

3 Ahmed N. S., Nassar A. M., Zaki N. N., Gharieb H. K. Formation of fluid heavy oil-in-water emulsions for pipeline transportation // Fuel. - 1999. - Vol.78, Is.5. - P.593-600.

4 Czarnecki, J. Stabilization of water in crude oil emulsions. Part 2 //Energy \& fuels. - 2009. - Vol. 23, Is.3. - P. 1253-1257.

5 Razi M., Rahimpour M. R., Jahanmiri A., Azad F. Effect of a different formulation of demulsifiers on the efficiency of chemical demulsification of heavy crude oil // Journal of Chemical \& Engineering Data. - 2011. - Vol.56, Is.6. - P.2936-2945.

6 Nikkhah M., Tohidian T., Rahimpour M. R., Jahanmiri A. Efficient demulsification of water-in-oil emulsion by a novel nanotitania modified chemical demulsifier // Chemical Engineering Research and Design. - 2015. - Vol.94. - P.164-172.

7 Otarbaev N. S., Kapustin V. M., Nadirov K. S., Bimbetova G. Z., Zhantasov M. K., Nadirov R. K. New Potential Demulsifiers Obtained by Processing Gossypol Resin // Indonesian Journal of Chemistry. - 2019. - Vol.19, Is.4. - P.959-966.

8 Balsamo M., Erto A., Lancia A. Chemical demulsification of model water-in-oil emulsions with low water content by means of ionic liquids // Brazilian Journal of Chemical Engineering. - 2017. - Vol.34, Is.1. - P.273-282.

9 Pradilla D., Ramírez J., Zanetti F., Álvarez O. Demulsifier performance and dehydration mechanisms in colombian heavy crude oil emulsions // Energy \& Fuels. - 2017. - Vol.31, Is.10. - P.10369-10377

10 Azizi K., Nikazar M. Characterization of chemical demulsification of oil in water emulsion: comparison between a kinetics model and laboratory experiments // Petroleum Science and Technology. - 2015. - Vol.33, Is.1. - P.8-14.

11 Xu X., Cao D., Liu J., Gao J., Wang X. Research on ultrasound-assisted demulsification/dehydration for crude oil // Ultrasonics sonochemistry. - 2019. - Vol.57. - P.185-192. 
12 Antes F. G., Diehl L. O., Pereira J. S., Guimarães R. C., Guarnieri R. A., Ferreira B. M., Flores E. M. Feasibility of low frequency ultrasound for water removal from crude oil emulsions // Ultrasonics sonochemistry. - 2015. - Vol.25. - P.70-75.

13 Khajehesamedini A., Sadatshojaie A., Parvasi P., Rahimpour M. R., Naserimojarad M. M. Experimental and theoretical study of crude oil pretreatment using low-frequency ultrasonic waves // Ultrasonics sonochemistry. - 2018. - Vol.48. - P.383-395.

14 Guoxiang Y., Xiaoping L. Ü., Fei P., Pingfang H., Xuan S. H. E. N. Pretreatment of crude oil by ultrasonic-electric united desalting and dewatering / /Chinese Journal of Chemical Engineering. - 2008. - Vol.16, Is.4. - P.564-569.

15 Ye G., Lu X., Han P., Shen X. Desalting and dewatering of crude oil in ultrasonic standing wave field // Journal of Petroleum Science and Engineering. - 2010. - Vol.70, Is.1-2. - P.140-144.

16 Yang X. G., Tan W., Tan X. F. Demulsification of crude oil emulsion via ultrasonic chemical method // Petroleum Science and Technology. - 2009. - Vol.27, Is.17. - P.2010-2020.

17 Antes F. G., DiehI L. O., Pereira J. S., Guimarães R. C., Guarnieri R. A., Ferreira B. M., Flores E. M. Effect of ultrasonic frequency on separation of water from heavy crude oil emulsion using ultrasonic baths // Ultrasonics sonochemistry. - 2017. - Vol.35. - P.541546.

18 Luo X., Gong H., Cao J., Yin H., Yan Y., He L. Enhanced separation of water-in-oil emulsions using ultrasonic standing waves // Chemical Engineering Science. - 2019. - Vol.203. - P.285-292.

\section{References}

1 Umar A A., Saaid I B M., Sulaimon A A, Pilus R B M (2018) J Petrol Sci Eng 165:673-690. https://doi.org/10.1016/j.petrol.2018.03.014

2 Czarnecki J, Tchoukov P, Dabros T (2012) Energ Fuel 26(9):5782-5786. https://doi.org/10.1021/ef300904a

3 Ahmed N S., Nassar A M, Zaki N N, Gharieb H K (1999) Fuel 78(5):593-600. https://doi.org/10.1016/S0016-2361(98)00157-4

4 Czarnecki J (2009) Energ Fuel 23 (3):1253-1257. https://doi.org/10.1021/ef800607u

5 Razi M, Rahimpour M R, Jahanmiri A, Azad F (2011) J Chem Eng Data 56(6):2936-2945. https://doi.org/10.1021/je2001733

6 Nikkhah M, Tohidian T, Rahimpour M R, Jahanmiri A (2015) Chem Eng Res Des 94:164-172. https://doi.org/10.1016/j. cherd.2014.07.021

7 Otarbaev N S, Kapustin V M, Nadirov K S, Bimbetova G Z, Zhantasov M K, Nadirov R K (2019) Indones J Chem 19(4):959-966. https://doi.org/10.22146/ijc.38671

8 Balsamo M, Erto A, Lancia A (2017) Braz J Chem Eng 34(1):273-282. https://doi.org/10.1590/0104-6632.20170341s20150583

9 Pradilla D, RamírezJ,Zanetti F, Álvarez O (2017) Energ Fuel31(10):10369-10377. https://doi.org/10.1021/acs.energyfuels. 7 b01021

10 Azizi K, Nikazar M (2015) Pet Sci Technol 33(1):8-14. https://doi.org/10.1080/10916466.2014.940088

11 Xu X, Cao D, Liu J, Gao J, Wang X (2019) Ultrason Sonochem 57:185-192. https://doi.org/10.1016/j.ultsonch.2019.05.024

12 Antes F G., Diehl L O, Pereira J S, Guimarães R C , Guarnieri R A, Ferreira B M, Flores E M (2015) Ultrason Sonochem 25:70-75. https://doi.org/10.1016/j.ultsonch.2015.01.003

13 Khajehesamedini A, Sadatshojaie A, Parvasi P, Rahimpour M R, Naserimojarad M M (2018) Ultrason Sonochem 48: $383-395$. https://doi.org/10.1016/j.ultsonch.2018.05.032

14 Guoxiang Y, Xiaoping L Ü, Fei P, Pingfang H, Xuan S H E N (2008) Chin J Chem Eng 16(4):564-569. https://doi.org/10.1016/S10049541(08)60122-6

15 Ye G, Lu X, Han P, Shen X (2010) J Petrol Sci Eng 70(1,2):140-144. https://doi.org/10.1016/j.petrol.2009.11.005

16 Yang X G, Tan W, Tan X F (2009) Pet Sci Technol 27(17):2010-2020. https://doi.org/10.1080/10916460802637577

17 Antes F G., Diehl L O, Pereira J S, Guimarães R C, Guarnieri R A, Ferreira B M, Flores E M (2017) Ultrason Sonochem 35:541-546. https://doi.org/10.1016/j.ultsonch.2016.03.031

18 Luo X, Gong H, Cao J, Yin H, Yan Y, He L (2019) Chem Eng Sci 203:285-292. https://doi.org/10.1016/j.ces.2019.04.002 